\title{
Effects of Gates-Glidden, LAAxxess and Orifice Shaper Burs on the Cervical Dentin Thickness and Root Canal Area of Mandibular Molars
}

\author{
Marco Antonio Hungaro DUARTE ${ }^{1}$ \\ Ricardo Affonso BERNARDES ${ }^{2}$ \\ Ronald ORDINOLA-ZAPATA ${ }^{1}$ \\ Bruno Carvalho de VASCONCELOS ${ }^{3}$ \\ Clovis Monteiro BRAMANTE ${ }^{1}$ \\ Ivaldo Gomes de MORAES ${ }^{1}$ \\ ${ }^{1}$ Department of Operative Dentistry, Dental Materials and Endodontics, Bauru Dental School, \\ USP - Univeristy of São Paulo, Bauru, SP, Brazil \\ ${ }^{2}$ Department of Endodontics, São Leopoldo Mandic Dental Research Center, Dental School, Brasília, DF, Brazil \\ ${ }^{3}$ Department of Endodontics, Federal University of Ceará, Sobral, CE, Brazil
}

\begin{abstract}
This study evaluated the increase of the instrumented area and dentin thickness in the mesial and distal aspects of mesial canals of mandibular molars after the use of Gates Glidden (GG), LAAxxess (LA) and Orifice Shaper (OS) instruments. A total of 53 canals from 27 mandibular molars were embedded in resin and divided into 3 groups. The roots were sectioned 3 mm below the cementoenamel junction and the images were captured before and after instrumentation. The increase of the instrumented area in terms of percentages and the remaining dentin thickness, in $\mathrm{mm}$, at the mesial and furcal aspects were calculated using the Image tools software. Data were analyzed using the Kruskal-Wallis and Dunn's test. The significance level was set at 5\%. All instruments promoted cervical flaring with different amounts of dentin removal at the mesial and distal aspects of the root canals. Statistically significant difference $(\mathrm{p}<0.05)$ was found between LA and all other instruments after using the first instrument. Regarding dentin thickness, no significant difference $(p>0.05)$ was found between the mesial and distal walls in all groups. It may be concluded that LA 35.06 and GG 3 burs produced the thinnest dentin walls, and thus their use in mesial canals of mandibular molars should be done with caution.
\end{abstract}

Key Words: cervical preparation, dental anatomy, cleaning and shaping procedures.

\section{INTRODUCTION}

The crown-down technique using rotary instruments is commonly used during the cleaning and shaping procedures of root canal treatment. This step minimizes cervical interferences and allows instruments to move freely inside the root canal during apical instrumentation by reducing the torque on canal walls and minimizing tensions on the file at the apical region (1). Additionally, cervical flaring favors reliable working length determination (2) and apical gauging (3-6).

The first rotary instruments used for cervical preflaring were Gates Glidden burs (7), which are still commonly used during endodontic procedures. The diameter of the Gates Glidden bur \#2 $(0.70 \mathrm{~mm})$ is generally considered safe for the cervical preflaring of mesial canals of mandibular molars (8), but it cannot completely remov cervical interferences, particularly below the cementoenamel junction (9). Isom et al. (10) studied the anti-curvature motion using Gates Glidden burs \#2 and \#3 and found significant dentin removal at the furcal aspect of the root canal (danger zone).

The search for new instruments to promote an appropriate cervical preparation has led to the development of nickel-titanium rotary instruments such as ProFile Orifice Shaper (Dentsply Tulsa Dental, Tulsa, OK, USA) and LA Axxess (SybronEndo, Orange, CA, USA). The former contains 6 instruments with $19 \mathrm{~mm}$

Correspondence: Prof. Dr. Marco Antonio Hungaro Duarte, Rua Anna Pietro Forte, 3-18, (lote A12), Residencial Villagio I, 17018-820 Bauru, SP, Brasil. Tel/Fax: +55-14-3234-6147. e-mail: mhungaro@travelnet.com.br 
in length, $10 \mathrm{~mm}$ of active portion, radial lands and different sizes. The latter consists of titanium nitritetreated stainless steel instruments with inactive tips. These instruments are 19-mm long and are available in sizes 20, 35 and 45 with 0.06 taper. The use of the LA Axxess instruments for flaring the cervical third has shown to favor a more precise apical gauging, providing more favorable apical widening of the canal $(3,4)$.

Preflaring is recommended in order to eliminate cervical interferences. One problem concerning the use of preflaring instruments is whether they could create an increased risk for perforations, especially in mesial root canals of mandibular molars. There is not a significant number of studies on the use of these instruments, especially the LA Axxess system during preparation of mesial canals of mandibular molars. Thus, the aim of this study was to evaluate the effects of cervical preflaring on mesial root canals of mandibular molars using three rotary instruments: LA Axxess, Orifice Shaper (Dentsply Maillefer, Ballaigues, Switzerland) and Gates Glidden burs.

\section{MATERIAL AND METHODS}

The present study was approved by local Research Ethics Committee (process \#137/2009). Fiftythree mesial canals from 27 mandibular molars were selected. The degree of the curvature was standardized as described by Schneider (11). Coronal access was performed using a \#1014 diamond bur (KG Sorensen, São Paulo, SP, Brazil) followed by a \#3082 safe-ended diamond bur (KG Sorensen). Then, the teeth were embedded in acrylic resin blocks using a flask system measuring $17 \mathrm{~mm}$ in height and $12 \mathrm{~mm}$ in width, according to the technique proposed by Bramante et al. (12). The flask could be opened or closed by 2 guiding pins and screws that provided stability to the assembly, preventing undesirable movements of the resin blocks. After acrylic resin curing, the blocks were removed and placed on an Isomet 1000 precision saw (Buehler, Lake Bluff, Chicago, IL, USA) equipped with a $0.3 \mathrm{~mm}$ diamond disc (Extec Corporation, Enfield, Connecticut, CT, USA). A horizontal section was made $3 \mathrm{~mm}$ below the cementoenamel junction.

The blocks were separated and the cervical areas of the teeth were photographed using a Nikon D70 digital camera equipped with a $\times 2$ zoom medical lens (Nikon, Tokyo, Japan). The resin blocks were reassembled in the flask and divided into 3 groups, according to the instruments used for cervical preflaring: group $1(\mathrm{n}=16)$ - Gates Glidden burs \#2 and \#3; group 2 ( $\mathrm{n}=18)$ - LA Axxess instruments 20.06 and 35.06; and Group 3 $(n=19)$ - Orifice Shaper instruments 30.06 and 40.06. A size $15 \mathrm{~K}$-file was inserted into the embedded teeth with anti-curvature movements before the use of the rotary instruments in order to verify the orientation of the canal axis and the absence of obstructions or ledge. For cervical preflaring, all the instruments evaluated were inserted $1 \mathrm{~mm}$ beyond the crosscut area ( $4 \mathrm{~mm}$ below the cement-enamel junction). The rotary instruments were used in an Endo-Plus engine motor (Driller, São Paulo, SP, Brazil), at 12,000 rpm for the Gates Glidden and LAAxxess burs, and $500 \mathrm{rpm}$ for the Orifice Shaper instruments. After using the first instrument in each group, the resin blocks with the teeth were removed from the flask and new images were captured. The blocks were then reassembled and the second instruments were used. After that, final photographs were taken.

The pre and post-instrumentation images of the root canal were imported to the Image Tools 3.01 software (UTHSCSA, San Antonio, TX, USA) running on a Windows XP operational system. The total area of the root canal before and after the use of each instrument was measured. Then, the increase of the instrumented area in terms of percentage was calculated. Furthermore, the thickness of the mesial and distal walls (danger zone) was established. Data were subjected to statistical analysis. Comparisons of the increase of the instrumented area and dentin thickness among the groups were performed using the Kruskal-Wallis test and individual comparisons were carried out by the Dunn's test. The significance level was set at 5\%.

\section{RESULTS}

Table 1 presents the increase of the instrumented area in terms of percentage. There were significant differences $(\mathrm{p}<0.05)$ among the instruments. LAAxxess instrument 20.06 removed significantly more dentin than Gates- Glidden \#2 and Orifice Shaper 30.06. After the use of the second instrument, the LA Axess 35.06 increased significantly $(p<0.05)$ the area of the root canal in comparison to the OS 40.06 .

Table 2 shows the mean and standard deviation of dentin wall thickness on the initial, post-instrument 1 and post-instrument 2 images for each group in millimeters. Perforation occurred in only one root canal in the Gates-Glidden group. No statistically significant 
differences ( $p>0.05$ ) were found among the groups for the preoperative dentin wall thickness at the mesial and distal aspects of the root. No statistically significant differences $(p>0.05)$ were found for the postoperative dentin thickness among the groups after the use of the first or second instrument.

\section{DISCUSSION}

Preflaring of the cervical third decreases the tension of manual and rotary instruments during apical instrumentation by eliminating dentin projections (13), and also provides greater reliability when defining the working length and the apical gauging $(4,5,14)$. Several methodologies have been employed to assess the effect of endodontic instruments on dentin wall thickness such as: resin blocks (15), scanning electron microscopy (16), radiography $(17)$ and computer tomography $(18,19)$.

This study followed the methodology proposed

Table 1. Mean and standard deviation of the increase of the instrument area in percentages after the use of the 1 st and 2 nd instruments in each group.

\begin{tabular}{lccc}
\hline Group & 1st instrument & 2nd instrument & p value \\
\hline Gates-Glidden & $17.03 \pm 15.42^{\mathrm{Aa}}$ & $41.42 \pm 18.64^{\mathrm{ABb}}$ & 0.0001 \\
Orifice Shaper & $10.59 \pm 8.40^{\mathrm{Aa}}$ & $23.59 \pm 14.06^{\mathrm{Bb}}$ & 0.0001 \\
LA Axxess & $41.96 \pm 37.28^{\mathrm{Ba}}$ & $69.31 \pm 47.71^{\mathrm{Ab}}$ & 0.00006 \\
p value & 0.0005 & 0.0003 & \\
\hline
\end{tabular}

Uppercase letters in columns and lowercase letters in rows indicate statistically significance difference $(\mathrm{p}<0.05)$.

Table 2. Means ( $\mathrm{mm}$ ) and standard deviation of dentin wall thickness on the initial, post-instrument 1 and post-instrument 2 images in each group at the mesial and distal aspects of the root canal.

\begin{tabular}{lccccccc}
\hline \multirow{2}{*}{ Images } & \multirow{2}{*}{$\begin{array}{c}\text { Canal } \\
\text { aspect }\end{array}$} & \multicolumn{2}{c}{ Gates Glidden } & \multicolumn{2}{c}{ Orifice Shaper } & \multicolumn{2}{c}{ LA Axxess } \\
\cline { 3 - 8 } & Mean & SD & Mean & SD & \multicolumn{2}{c}{ Mean } & SD \\
\hline \multirow{2}{*}{ Initial } & Mesial & 1.55 & 0.68 & 1.47 & 0.42 & 1.66 & 0.38 \\
& Distal & 1.12 & 0.26 & 1.31 & 0.50 & 1.40 & 0.40 \\
\multirow{2}{*}{ 1st Instrument } & Mesial & 1.32 & 0.28 & 1.41 & 0.42 & 1.45 & 0.33 \\
\multirow{2}{*}{ 2nd } & Distal & 1.02 & 0.21 & 1.23 & 0.51 & 1.15 & 0.39 \\
& Mesial & 1.27 & 0.26 & 1.28 & 0.35 & 1.34 & 0.29 \\
& Distal & 0.83 & 0.29 & 1.11 & 0.51 & 1.04 & 0.33 \\
\hline
\end{tabular}

by Bramante et al. (12), which involves embedding teeth in resin blocks held by a flask. This technique allows the teeth to be sectioned and the root canal area and the thickness of the dentin walls to be compared before and after instrumentation by analyzing the digitized images using specific software. This technique can also be carried out by micro-computed tomography $(\mu \mathrm{CT})$, but it is time consuming, expensive and not always readily available.

It has been reported that manual insertion of files before rotary instrumentation minimizes the risk of perforations during cervical preflaring (19). For this reason, in the present study, a \#15 K-file was inserted into each canal with anti-curvature movements before the use of the rotary instruments. The results of this study showed that the LA Axxess 35.06 instrument promoted a greater increase in canal area as well as greater dentin removal. On the other hand, Gates Glidden \#3 showed the lowest values of dentin thickness at the furcal level. As Gates Glidden \#3 has a diameter of $0.90 \mathrm{~mm}$ and no taper, it is possible that a fulcrum effect at the orifice level move the blade of the Gates Glidden bur toward the furcal aspect of the canal wall. In fact, Wu et al. (1) showed that anti-curvature filing movements does not reduce the risk of perforation by Gates Glidden burs. Furthermore, in the present study, the LAAxxess instruments and the GatesGlidden burs were used at 20,000 rpm, increasing the cutting action while Orifice Shaper was used at $500 \mathrm{rpm}$. In addition, these instruments present radial lands with a less effective cutting action. This might have contributed to the lower dentin removal capacity of these instruments.

All instruments removed dentin on the mesial and distal aspects of the root canal. Similar rates of dentin removal on the mesial and dentin walls were also observed in previous studies $(1,8)$. However, Mahran et al. (18) verified by multislice 
computer tomography analysis, greater dentin removal on the distal wall when Gates Glidden burs were used for cervical flaring prior to apical instrumentation. The greater dentin removal capacity of the LA Axxess instruments eliminate cervical interferences because they can cut at the root canal, at the orifice level and in dentin walls at the pulp chamber level at the same time. This allows a more precise apical gauging in comparison to other types of instruments, as previously reported (3$6,20)$. However, it should be pointed out that a balance between preflaring and dentin thickness should be reached. Therefore, it seems recommendable the use of the LA Axxess 20.06, Gates Glidden \#2 and Orifice Shapers for preflaring mesial root canals of mandibular molars. Within the limitations of this study, it is possible to conclude that all instruments increased significantly the root canal area and removed dentin from the mesial and the distal wall (danger zone). Caution should be taken when using Gates Glidden \#3 and LA Axxess 35.06 for cervical preflaring.

\section{RESUMO}

Este estudo avaliou o aumento da área do canal e a espessura de dentina na parede mesial e distal dos canais mesiais de molares inferiores após o uso de Gates Glidden (GG), La Axxess (LA), Orifice Shaper (OS). Um total de 53 canais mesiais de 27 molares inferiores foram incluídos em resina e divididos em 3 grupos. As raízes foram seccionados $3 \mathrm{~mm}$ abaixo da junção cemento-esmalte e as imagens foram capturadas antes e depois da instrumentação. $\mathrm{O}$ aumento da área do canal em percentagem e a espessura da dentina remanescente nas paredes mesial e furca foram calculados utilizando o software Image Tools. Os dados foram analisados utilizando o Kruskal-Wallis e teste de Dunn. O Nível de significância foi de 5\%. Todos os instrumentos promoveram o aumento da área cervical, com diferentes quantidades de remoção da dentina nas paredes mesial e distal do canal radicular. Diferença estatística $(p<0,05)$ foi encontrada entre LA e todos os outros instrumentos após o uso do primeiro instrumento. Quanto à espessura da dentina, não houve diferença significativa ( $p>0,05$ ) entre as paredes mesial e distal de todos os instrumentos analisados. O LA 35.06 e GG 3 mostraram a menor espessura da parede e sua utilização em canais mesiais de molares inferiores deve ser feito com cuidado.

\section{REFERENCES}

1. Wu MK, van der Sluis LWM, Wesselink PR. The risk of furcal perforation in mandibular molars using Gates-Glidden drills with anticurvature pressure. Oral Surg Oral Med Oral Path Oral Rad and Endod 2005;99:378-382.

2. Davis RD, Marshall JG, Baumgartner JC. Effect of early coronal flaring on working length change in curved canals using rotary nickel-titanium versus stainless steel instruments. J Endod 2002;28:438-442.
3. Barroso JM, Guerisoli DM, Capelli A, Saquy PC, Pecora JD Influence of cervical preflaring on determination of apical file size in maxillary premolars: SEM analysis. Braz Dent J 2005; 16:30-34

4. Vanni JR, Santos R, Limongi O, Guerisoli DM, Capelli A, Pecora JD. Influence of cervical preflaring on determination of apical file size in maxillary molars: SEM analysis. Braz Dent J 2005; 16:181186.

5. Schmitz Mda S, Santos R, Capelli A, Jacobovitz M, Spano JC, Pecora JD. Influence of cervical preflaring on determination of apical file size in mandibular molars: SEM analysis. Braz Dent J 2008; 19:245-251.

6. Ibelli GS, Barroso JM, Capelli A, Spano JC, Pecora JD. Influence of cervical preflaring on apical file size determination in maxillary lateral incisors. Braz Dent J 2007;18:102-106.

7. Schilder H. Cleaning and shaping the root canal. Dent Clin North Am 1974;18:269-296.

8. Zuckerman O, Katz A, Pilo R, Tamse A, Fuss Z. Residual dentin thickness in mesial roots of mandibular molars prepared with Lightspeed rotary instruments and Gates-Glidden reamers. Oral Surg Oral Med Oral Pathol Oral Radiol Endod 2003;96:351-355.

9. Busquim SS, dos Santos M. Cervical shaping in curved root canals: comparison of the efficiency of two endodontic instruments. Braz Oral Res 2002;16:327-331.

10. Isom TL, Marshall JG, Baumgartner JC. Evaluation of root thickness in curved canals after flaring. J Endod 1995;21:368-371.

11. Schneider SW. A comparison of canal preparations in straight and curved root canals. Oral Surg Oral Med Oral Pathol 1971;32:271 275.

12. Bramante CM, Betti LV. Efficacy of Quantec rotary instruments for gutta-percha removal. Int Endod J 2000;33:463-467.

13. Constante IG, Davidowicz H, Barletta FB, Moura AA. Location and angulation of curvatures of mesiobucal canals of mandibular molars debrided by three endodontic techniques. Braz Oral Res 2007;21:22-28

14. Lazzaretti DN, Camargo BA, Della Bona A, Fornari VJ, Vanni JR, Baratto Filho F. Influence of different methods of cervical flaring on establishment of working length. J Appl Oral Sci 2006;14:351354.

15. Weine FS, Kelly RF, Lio PJ. The effect of preparation procedures on original canal shape and on apical foramen shape. J Endod $1975 ; 1: 255-262$

16. Mizrahi SJ, Tucker JW, Seltzer S. A scanning electron microscopic study of the efficacy of various endodontic instruments. J Endod $1975 ; 1: 324-333$

17. Southard DW, Oswald RJ, Natkin E. Instrumentation of curved molar root canals with the Roane technique. J Endod 1987;13:479489.

18. Mahran AH, AboEl-Fotouh MM. Comparison of effects of ProTaper, HeroShaper, and Gates Glidden Burs on cervical dentin thickness and root canal volume by using multislice computed tomography. J Endod 2008;34:1219-1222.

19. de Alencar AH, Dummer PM, Oliveira HC, Pécora JD, Estrela C. Procedural errors during root canal preparation using rotary NiTi instruments detected by periapical radiography and cone beam computed tomography. Braz Dent J 2010;21:543-549.

20. Coutinho-Filho T, De-Deus G, Gurgel-Filho ED, Rocha-Lima AC, Dias KR, Barbosa CA. Evaluation of the risk of a stripping perforation with Gates-Glidden drills: serial versus crown-down sequences. Braz Oral Res 2008;22:18-24.

21. Pecora JD, Capelli A, Guerisoli DM, Spano JC, Estrela C. Influence of cervical preflaring on apical file size determination. Int Endod J 2005;38:430-435. 